\title{
Predicting School-Based Assessment Practice of Teachers in Senior Secondary Schools in Ijebu Division of Ogun State, Nigeria
}

\author{
${ }^{1}$ Abiodun Adebowale OJO, ${ }^{2}$ Olufemi Abiodun AJAYI, ${ }^{3}$ Falilat OUSOLA \\ 1,2 \& 3 Department of Educational Foundations \& Instructional Technology \\ Tai Solarin University of Education, Ijagun, Nigeria \\ abiodunojoade@yahoo.com¹,olufemi_jy@yahoo.com², fadeeflah@gmail.com³ \\ DOI: https://doi.org/10.37134/ajatel.vol8.6.2018
}

Received: 25 April 2018; Accepted: 15 July 2018; Published: 21 December 2018

\begin{abstract}
The significance of school-based assessment is being undermined by inadequacies inherent in the process. Stakeholders' efforts and research attempts at improving the situation have not yielded desired results. It was on this premise, the researchers sought to predict school-based assessment practice of senior secondary teachers from their SBA knowledge and attitudes towards SBA in Ijebu Division of Ogun State, Nigeria. Descriptive survey design was adopted. A sample of four hundred $(\mathrm{n}=400)$ teachers were selected as participants using simple random sampling techniques. The three instruments for data collection were Teachers Knowledge of Assessment Technique $(r=.62)$, Teachers Attitudes towards SBA scale $(\mathrm{r}=.74)$ and School-Based Assessment Practice of Teachers Questionnaire $(\mathrm{r}=.69)$. The results indicated that both predictors account for $5.1 \%(\mathrm{R}=.051 ; \mathrm{P}<.05)$ of variance in the criterion. Only SBA knowledge in the hypothesized model was a significant predictor $(\mathrm{B}=.223 ; \mathrm{P}<.05)$ of school-based assessment practice of teachers. Therefore, it was recommended that the government policy which prescribes that only professional teachers are retained in the profession be strictly enforced.
\end{abstract}

Keywords: School-based assessment practice, SBA knowledge, Attitudes towards SBA, Predictors

\section{INTRODUCTION}

Assessment is essentially an important aspect of classroom instruction, yielding information on learning outcomes being recorded by the learners. Assessment according to Aduloju, Adikwu and Agi (2016) is a process by which information relating to learning outcomes among learners are collected, interpreted and reported back to learners and their parents. Assessment information is useful to the learners for improved performance, to the teachers for accountability purpose and to the school management and policy makers for quality assurance. The assessment information enables the teachers to refine and clarify the instructional objectives, modify the teaching methods, revisit classroom interactions and review assessment and evaluation procedure. Assessment being an integral part of the teaching and learning process is so crucial that in the absence of it no educational enterprise will survive.

The conventional assessment procedure involving the use of one-short end of term or year examination which has been in use since the advent of western education in Nigeria has been found to be inadequate and so was replaced with continuous assessment a few decades ago. Amongst other limitations of conventional assessment procedure was the restriction to cognitive domain of learning only, leaving behind the other two domains, assessment of learning (curriculum) goals excluding actual performance realities and of no/little direct positive impacts to the teaching and learning process. Heffner (2004) asserted that paper and pencil test measures cognitive abilities only to the exclusion of the affective and psychomotor domains of learning. The conventional assessment procedure projects assessment of learning. The wave of educational reforms sweeping across nations Nigeria inclusive of 
the world has brought about a paradigm shift from 'assessment of learning' to 'assessment for learning' Assessment for learning translates to school-based assessment (SBA) while assessment of learning is retained for external examination-based assessment (Adediwura, 2012).

According to Nworgu and Ellah (2015), SBA is a type of assessment that enables the teacher to continually assess the learners in a stress-free environment, reducing the reliance on one-short public examination, reinforcing learner autonomy, independent learning and ultimately empowering the teacher on the different modes of assessment and mechanisms that reflect the ability of the learner underpinned by confidence that every learner can improve. With SBA, expression of reluctance, fear and anxiety is removed from the learners. SBA is comprehensive in terms of attention being given to cognitive, affective and psychomotor domains of learning, systematic (planned procedure), cumulative (additive) and guidance-oriented (Aduloju, Adikwu \& Agi, 2016). It is a kind of assessment that employs diverse assessment techniques such as tests, quizzes, question and answer session, short writing, drama, role-play, interview, questionnaire, project, assignment and presentation (Mkpae \& Obowu-Adutchay, 2017; Mansor, Leng, Rasul, Raof \& Yusoff, 2013; Davidson, 2007). Cumulative marks and grades of learners from SBA complement the marks generated for learners from external examination-based assessment after the completion of educational programme cycle.

The assessment in SBA is undertaken by the teacher, the learner and peers based on what has been taught and the background under which teaching and learning process has taken place. The learner enjoys the privilege of being involved in his/her assessment. The focus of SBA is attainment of educational goals encapsulated in generic skills. Information from assessment of leaning outcomes provides constructive feedback opportunity for the teacher to improve his instructional techniques, monitor and improve the learner's performance. There is no doubt, the assessment innovation as good as it is puts a lot of demands on the teacher. From observation the integration of the innovation in Nigerian secondary schools has not been fully realized. Adediwura (2012) in his study on teachers' perception of SBA in Nigerian secondary schools reported that less than half the sampled number of teachers predominantly in Federal Government colleges was really prepared for the conduct of SBA in the schools. The author supported by Mkpae and Obowu-Adutchay (2017) asserted further that teachers in Nigerian secondary schools did not feel the need to embrace SBA.

However, Mkpae and Obowu-Adutchay (2017) revealed that more than half the number of teachers sampled demonstrated understanding of the requirements and procedures involved in SBA. In contrast, Nworgu and Ellah (2015) reported otherwise, claiming that teachers with varying number of years of experience exhibited difficulty in understanding the important development stages of test construction as well as the practice of SBA techniques. The authors reported further that SBA techniques involving the use of matching type of items, projects, group work, peer assessment, questionnaires, interviews, portfolios, debriefing, checklists and anecdotal records were ignored by science teachers in Benue state of Nigeria. Unarguably, the relevance of diversity of assessment instruments: paper and pencil test, interview schedule, observational schedule, rating scale, anecdotal records, socio-metric test and others in terms of being complimentary to one another and offering an ample opportunity to assess the three domains of learning cannot be overemphasised in SBA. Osunde (2008) reported that most of the teachers in the Nigerian secondary schools lacked adequate skills to develop and validate teacher made tests for use in SBA.

Essentially, teachers' knowledge of SBA and attitude towards SBA seemingly appear important in proper implementation of SBA. SBA knowledge of teachers as it relates to assessment techniques viz a viz assessment instruments, procedures, interpretation of learning outcomes and reporting practices is of interest in explaining SBA practice among teachers of Senior Secondary schools in Ogun state, Nigeria. The second factor presumed to be of relevance in predicting the SBA practice of the teachers is their attitude towards SBA. This of course is an expression of individual disposition to implementation of SBA in the school setting. Campbell and Evans (2000) evaluated pre-service teachers who had completed coursework in educational measurement and found that they did not follow many assessment practices prescribed during their coursework.

Nneji, Fatade, Awofala \& Awofala (2012) investigated the attitudes of 305 Science, Technology and Mathematics (STM) teachers towards assessment practices in Nigeria within the blueprint of descriptive survey research and findings showed that a higher proportion of the STM teachers seemed to display positive attitudes towards most of the assessment practices, while their attitudes towards a few other assessment practices tended to be either negative or neutral. They found 
that teaching experience and professional status might be factors in STM teachers' attitudes towards assessment practice.

From the literature above, it becomes clear that attitudes of teachers towards SBA vary widely while their SBA knowledge appears to be poor. Consequently as it seems to be, quite a number of inadequacies were reported in literature and observed in the way teachers go about SBA. An attempt to provide explanation for these inadequacies prompted a look in the direction of factors that seemingly appear to influence the conduct of SBA. Considering logic, theory and experience, SBA knowledge and attitudes of teachers towards SBA were selected for investigation with a view to determine the proportion of variance in SBA practice of teachers attributable to the two factors severally and collectively.

\section{STATEMENT OF THE PROBLEM}

School-based assessment (SBA) is significant to the extent it is able to yield credible, valid and reliable measures indicating learning outcomes using efficient technique. Controversies have always trailed the genuineness of scores awarded by teachers from students and parents of the students alike. Apart from this, quite a number of inadequacies such as departure from cumulative, comprehensive, systematic and guidance-oriented nature of SBA were noticed among the teachers. Efforts of previous researchers were carefully noted and acknowledged but the findings are not consistent and so remain inconclusive. Thus, this study sought to predict school-based assessment (SBA) practice of senior secondary teachers using their SBA knowledge and attitudes towards SBA

\section{STUDY OBJECTIVES}

The purpose of this study was to predict school-based assessment practice of senior secondary teachers using the factors of SBA knowledge and attitudes towards SBA. However, the specific objectives of the study were to determine:

1. the composite contribution of SBA knowledge and attitudes of teachers to SBA practice

2. the relative influences of SBA knowledge and attitudes of teachers to SBA practice

\section{RESEARCH QUESTIONS}

1. What is the composite contribution of teachers' SBA knowledge and attitudes to SBA practice?

2. What are the relative influences of teachers' SBA knowledge and attitudes to SBA practice?

\section{RESEARCH METHODS}

The study adopted a descriptive survey design, in which case the variables of the study were not manipulated but only measured as existed in the population. The target population comprised all senior secondary teachers in Ijebu Division of Ogun State Nigeria.

The participants of the study were four hundred $(n=400)$ teachers. Four out of six Local Government Areas (LGAs) were purposively selected on the basis of contiguity to one another, and at the same time they represented rural and urban settings. From each LGA five schools were selected and from each school twenty teachers were selected. Selection at both levels of the school and population were by simple random sampling technique.

Three instruments namely Teacher's Knowledge of Assessments Technique Scale (TKATS), Teachers Attitude towards SBA Scale (TATSBAS) and School-Based Assessment Practice of Teachers Questionnaire (SBAPTQ) were employed in data collection. TKATS was adapted from the original version developed by $\mathrm{Yu}$ (2004). It is a 15-item scale involving the use of four option response format: Strongly Disagree $(\mathrm{SD})=1$, Disagree $(\mathrm{D})=2$, Agree $(\mathrm{A})=3$ and Strongly Agree $(\mathrm{SA})=4$. The 
instrument measures the SBA knowledge of teachers in conducting assessment, use of various assessment type and competence in the development and scoring of assessment tools. TKATS had a Cronbach alpha coefficient of .62 TATSBAS was an adopted instrument developed by Ajayi (2015). It contained twenty items meant to capture teacher's attitude and how he considers himself ready for the conduct of SBA in the school. The scale was a four-point modified Likert scale using Strongly Disagree $(S D)=1$, Disagree $(D)=2$, Agree $(A)=3$ and Strongly Agree $(S A)=4$. The Cronbach alpha reliability coefficient of the instrument is .74. SBAPTQ, a - 17 item instrument was adopted wholesomely as developed by Ajayi (2011). The instrument measures actions and activities of the teachers in relation to implementation of school-based assessment requirements. The questionnaire scale was the same with the scale of the first two, it had a reliability coefficient of .69 using Cronbach alpha.

The instruments were administered to the participants in sequence of TKATS, TATSBAS and SABPTQ having secured their cooperation earlier. Data collected were analysed using multiple regression at .05 level of significance.

\section{FINDINGS AND RESULTS}

RQ1: What is the composite contribution of teachers' SBA knowledge and attitudes to SBA practice?

Table 1: Summary of Regression Analysis indicating joint contribution of SBA knowledge and attitudes of teachers to SBA practice

\begin{tabular}{|llllll|}
\hline $\begin{array}{l}\mathrm{R}=.226 \\
\mathrm{R}^{2}=.051 \\
\mathrm{R}^{2} \text { adj }=.046 \\
\mathrm{SE}=4.69624\end{array}$ & & & & & \\
\hline & SS & DF & MS & F & Sig \\
\hline Regression & 469.789 & 2 & 234.894 & 10.651 & .000 \\
Residual & 8755.709 & 397 & 22.055 & & \\
Total & 9225.498 & 399 & & & \\
& & & & & \\
\hline
\end{tabular}

The results in Table 1 show that SBA knowledge and attitudes of senior secondary teachers combined account for $5.1 \%\left(\mathrm{R}^{2}=.051 ; \mathrm{SE}=4.69624\right)$ of variance in SBA practice of the teachers. The test of significance of contribution indicate $\mathrm{F}_{(2,397)}=10.651$ at $\mathrm{P}<.05$, which implies the joint contribution of the two predictors to the criterion is significant.

RQ2: What are the relative influences of teachers' SBA knowledge and attitudes to SBA practice? 
Table 2: Regression Weights of Predictors to SBA practice of Senior Secondary teachers

\begin{tabular}{|c|c|c|c|c|c|}
\hline \multirow[t]{2}{*}{ Model } & \multicolumn{2}{|c|}{ Unstandardized Coefficient } & \multirow{2}{*}{$\begin{array}{l}\text { Standardized } \\
\text { Coefficients } \\
\text { Beta }\end{array}$} & \multirow[t]{2}{*}{$\mathrm{T}$} & \multirow[t]{2}{*}{ Sig } \\
\hline & $\mathrm{B}$ & Std. Error & & & \\
\hline Constant & 35.965 & 3.236 & & & \\
\hline SBA knowledge & .223 & .057 & .195 & 3.951 & .000 \\
\hline Attitudes towards SBA & .086 & .047 & .090 & 1.823 & .069 \\
\hline
\end{tabular}

Considering the results presented in Table 2 , SBA knowledge of teachers significantly predicted $(\mathrm{B}=.223 ; \mathrm{P}<.05)$ SBA practice of the teachers. Attitudes of the teachers is the second predictor with $8.6 \%$ prediction strength $(\mathrm{B}=.086 ; \mathrm{P}>.05)$ on the criterion. However, the prediction strength was not significant.

\section{FINDINGS AND DISCUSSION}

SBA knowledge and attitudes of senior secondary teachers combined significantly accounts for variance in the school-based assessment practice. Though, the percentage contribution of the two variables combined was low, the fact remains they constitute a significant proportion of a chunk of variables that would eventually make up a parsimonious model of the criterion. Disaggregating the prediction strength of the variables, SBA knowledge of teachers was found to be of high influence on SBA practice of the participants of the study. In addition, the influence of this predictor was a significant one. This finding is in support of an assertion made by Osunde (2008) that Nigerian secondary school teachers lacked requisite skills to validate teacher made tests for use in SBA. The finding also corroborates the assertion of Lukman and Uwadiegwu (2012) which states that teachers' training in assessment techniques was a major challenge facing implementation of SBA in Nigerian educational system. In addition, the finding was in consonance with the postulation of Adediwura (2012) and Mkpae and Ellah (2015) that teachers were lacking in requisite knowledge of SBA. The explanation for the findings is that the conduct of SBA placed on shoulders of teachers among other things great responsibilities that require expertise acquired only by professional training to perform. Once the training is deficient and periodic training and retraining of teachers is absent, what is obtained is nothing better behaviour exhibited by a quack. The popular saying that you cannot give what you do not have will definitely hold sway.

Attitude of the teachers towards classroom instruction was the other predictor of SBA practice, but its influence was found not significant. Explanation for the attitudes of teachers in terms of opinions held about SBA was captured by Nworgu and Ellah (2015) who reported that the teachers attitudes towards conduct of SBA were inadequate or better still poor. Adediwura (2012) established further the reasons for poor implementation of SBA in the schools with the claim that teachers' attitudes towards SBA though varied remarkably were predominantly negative as they considered SBA too difficult to put into practice. Further explanation provided by Nneji, Fatade, Awofala \& Awofala (2012) indicated that Science, Technology and Mathematics (STM) teachers developed varied dimensions of attitudes towards structured assessment practices in the school. Attitude is an in-built or innate factor and it rules greater proportion of human actions and inactions. 


\section{CONCLUSION AND RECOMMENDATIONS}

Baring the findings of this study, SBA knowledge of teachers in service should be queried before stakeholders in education can anticipate valid, reliable and effective school-based assessment. Apart from this, personality dimension of the teachers involving attitudes should not be ignored, if we hope to get desirable school-based assessment outcomes. While focus is placed on these two variables, all other aspects of the school and members of the school community that are relevant for the overall success of the school must be properly maintained and sustained. On this note, the following recommendations are offered;

1. The policy of the government which prescribes that only professional teachers be made to operate the school system should be strictly enforced without any waiver.

2. Universities and Faculties of Education and other teacher training institutions should be more alive and conscious of their responsibility to produce teachers who are skilled, intellectually sound and morally upright for the nation.

3. Training and retraining of pre-service teachers for enhanced skills more so in the area of SBA should be a regular project of the school system sponsored by the government and nongovernmental organizations (NGOs).

\section{REFERENCES}

Adediwura, A. A. (2012). Teacher's perception of school-based assessment in Nigeria secondary schools. Mediterranean Journal of Social Sciences. 3 (1), 99-109

Aduloju, M. O., Adikwu, O. \& Agi, C. I. (2016). School based assessment: Implication for national development. Open Access Library Journal 3 (3), 1-8

Ajayi, F. A. (2015). School climate, staff welfare and administrative practice of head teachers of primary schools as predictors of teacher efficiency. Unpublished M.Ed Dissertation submitted to the Department of Educational Management, Tai Solarin University of Education, Ijagun, Nigeria

Ajayi, O. A., \& Bamiro, O. A. (2011). Computer literacy and school based assessment practice of primary school teachers. Journal of Education and Applied Psychology, 4(1), 29-40.

Campbell, C. \& Evans, J. A. (2000). Investigation of preservice teachers' classroom assessment practices during students' teaching. The Journal of Educational Research. 93 (6), 350-355.

Heffner, C. L. (2004). Psychology 101: Memory, intelligence and states of mind. Retrieved on 23/11/2004 from www.Allpsych.com/psychology 101

Lee, S. K. J., Yu, K. (2004). Corporate culture and organizational performance. Journal of Managerial Psychology, 19 (4), 340-359

Lukman, S. A. \& Uwadiegwu, A. A. (2012). School-based assessment as an innovation in Nigeria educational system: The implementation challenges. Knowledge Review. 25 (1), 123-127

Mansor, A. N., Leng, O. H., Rasul, M. S., Raof, R. A. \& Yusoff, N. (2013). The benefits of schoolbased assessment. Asian Social Science; 9 (8), 101-106

Mkpae S. G. \& Obowu-Adutchay V. (2017). School-based assessment: Benefit and teachers' perception in Nigerian secondary schools. International Journal of Education and Evaluation. 3 (2), 19-27

Nneji, L. M. Fatade, A. O., Awofala, A. A. \& Awofala, A. O. A. (2012) The Attitude of some Nigerian Science, Technology, and Mathematics teachers towards assessment practices, International Journal of Mathematics Trends and Technology, 3 (3), 110-116

Nworgu, L. N. \& Ellah, B. O. (2015). Teachers practice of school-based assessment (SBA) techniques in science classes. International Journal of Education Research. 14 (2), 242-251

Osunde, A. U. (2008). The relevance of evaluation of teaching and learning in the school system. In P. N. C. Ngwu (Ed) The principal and education reforms in Nigeria. A publication of the Mandatory Continuing Professional Training (MCPT) programme of the All Nigerian Conference of Secondary Schools (ANCOPSS). 